\title{
Online Booking Systems for Managing Queues at The Road Transport Department
}

\author{
E., Mohamad"1 , I., Anak Jiga ${ }^{1}$, R., Rahmat ${ }^{1}$, A., Azlan ${ }^{1}$, M.S., Abd Rahman ${ }^{2}$ and A., \\ Saptari ${ }^{3}$ \\ ${ }^{1}$ Fakulti Kejuruteraan Pembuatan, Universiti Teknikal Malaysia Melaka, Hang Tuah Jaya, 76100 \\ Durian Tunggal, Melaka, Malaysia \\ ${ }^{2}$ Fakulti Teknologi Kejuruteraan Mekanikal dan Pembuatan, Universiti Teknikal Malaysia Melaka, \\ Hang Tuah Jaya, 76100 Durian Tunggal, Melaka, Malaysia \\ ${ }^{3}$ Department of Industrial Engineering, President University, Jl. Ki Hajar Dewantara, Kota Jababeka, \\ Cikarang Baru, Bekasi 17550 - Indonesia
}

Email: *1effendi@utem.edu.my, *1ivianajiga@gmail.com, *1rashitah_rahmat@silterra.com, *1alyaanorazlan@gmail.com , *2soufhwee@utem.edu.my and *3adi.saptari@president.ac.id

\begin{abstract}
In Malaysia, the Road Transport Department (RTD) is one of the public sectors facing the issue of having excessive waiting times at their service counter. Various alternatives have been proposed to address this problem, such as implementing an e-government service via the official RTD portal and creating other units so that the demand can be segregated, which also involves the creation of other agencies including myEG and UTC. However, the problem has persisted and has even become one of the most urgent policy issues that plague the RTD. Thus, this study aims to propose an online system that will help manage queue during the service and therefore optimise the waiting time. Several methods were employed to achieve the objectives, including conducting semi-structure interview, observation, and time study at RTD Bukit Katil, Melaka, developing the online system with Adobe Dream Weaver, Oracle SQL Developer software, and Adobe Cold Fusion, and validating and verifying the system using usability studies and questionnaires. The first online system involves an online queue number booking system. With this developed system, clients can use an online system to book their queue number. Furthermore, this system provides clients with the duration of the waiting time so that they can be present at the counter in time before their assigned service. The second proposal involves utilising an online queue booking system. With this system, clients can book their appointment according to the specific time with the RTD staff. This system also makes it possible for the client to come and to be serviced on time. This system aims to optimise the waiting time at the RTD, improve customer satisfaction, and serve as a reference for other government agencies so that their services can be improved
\end{abstract}

KEYWORDS: Queue, Online booking system, Public Sector, Semi-structure interview, Time study.

\begin{abstract}
Abstrak
Di Malaysia, Departemen Transportasi Jalan (RTD) adalah salah satu sektor publik yang menghadapi masalah memiliki waktu tunggu yang berlebihan di konter layanan mereka. Berbagai alternatif telah diusulkan untuk mengatasi masalah ini, seperti menerapkan layanan e-government melalui portal RTD resmi dan membuat unit lain sehingga permintaan dapat dipisahkan, yang juga melibatkan pembentukan lembaga lain termasuk myEG dan UTC. Namun, masalahnya tetap ada dan bahkan menjadi salah satu masalah kebijakan paling mendesak yang mengganggu RTD. Dengan demikian, penelitian ini bertujuan untuk mengusulkan sistem online yang akan membantu mengelola antrian selama layanan dan karenanya mengoptimalkan waktu tunggu. Beberapa metode digunakan untuk mencapai tujuan, termasuk melakukan wawancara semi-struktur, observasi, dan studi waktu di RTD Bukit Katil, Melaka, mengembangkan sistem online dengan Adobe Dream Weaver, perangkat lunak Oracle SQL Developer, dan Adobe Cold Fusion, serta memvalidasi dan memverifikasi sistem menggunakan studi kegunaan dan kuesioner. Sistem online pertama melibatkan sistem pemesanan nomor antrian online. Dengan sistem yang dikembangkan ini, klien dapat menggunakan sistem online untuk memesan nomor antrian mereka. Selain itu, sistem ini memberikan durasi waktu tunggu kepada klien sehingga mereka dapat hadir di konter tepat waktu sebelum layanan yang diberikan. Proposal kedua melibatkan penggunaan sistem pemesanan antrian online. Dengan sistem ini, klien dapat memesan janji temu mereka sesuai dengan waktu tertentu dengan staf RTD. Sistem ini juga
\end{abstract}


memungkinkan klien datang dan dilayani tepat waktu. Sistem ini bertujuan untuk mengoptimalkan waktu tunggu di RTD, meningkatkan kepuasan pelanggan, dan berfungsi sebagai referensi untuk lembaga pemerintah lainnya sehingga layanan mereka dapat ditingkatkan

Kata Kunci: Antrian, sistem pemesanan online, Sektor Publik, Wawancara semi-struktur, Studi waktu.

\section{Introduction}

Road and Transport Department (RTD) is one of the service providers in Malaysia's public sector. RTD, also called the Jabatan Pengankutan Jalan (JPJ), is supervised by the Ministry of Transport Malaysia. The vision of RTD is to be recognised as a World Class Road Transport Enforcement Management Organisation by 2020. Its mission is to manage road traffic safety and motor vehicles through efficient, respected, and advanced enforcement systems and service deliveries in order to satisfy the requirements of the customer and the nation, and ensure the professional growth and welfare of RTD citizens. In compliance to the British military law at Federal Malay States, RTD Malaysia was established in 1937. By 1st April 1946, the RTD's purpose was modified, which involves coordinating all road transportation aspects throughout the nation. It is the duty of RTD to provide counter services for driver and vehicles licensing, along with enforcing the Road Transport Act 1987, with the goal of ensuring driver and vehicle safety. Furthermore, the agency performed few internal restructuring to achieve a more efficient service that satisfies the current demand.

Nowadays, most government agencies are faced with the same dilemma - the problem of excessive waiting times. As a matter of fact, it is a strange issue that plagues the government sector since their staff needs need to attend to as many clients as they can and hundreds of customers come to their office to fulfil their transactions each day. Most of the customers are unsatisfied with the current service and the problem of long waiting times has become one of the most urgent policy issues that the government sector faces.

On December 2015, The Star News reported that Datuk Seri Liow Tiong Lai, the Minister of Transport, conducted a surprise check at RTD Wangsa Maju in response to a complaint he got from Twitter. He discovered that the license renewal queue was twice as long as the desired time [1]. Apart from the long waiting time, it was also observed that there was limited parking space due to the long queue. Saiful Azzri Hamzah, RTD State Director, also acknowledged this situation in the Sinar Harian newspapers (January 2014). However, he claimed that this issue was due to the numerous clients coming simultaneously. Furthermore, he mentioned that it is not possible for RTD to open more counters at the shopping mall since cost and many other factors have to be considered.

Certain approaches have to be implemented to manage the issue. One of the implemented approaches involved the use of current information system technology. The public service department of Malaysia has focused on "electronic government" ("e-government") in an attempt to improve quality by providing greater availability [2-5]. However, despite the emerging presence of quality principle among government agencies, there have not been thorough studies about the long waiting time [6]. Furthermore, despite the processes of automation, training intercessions, and advancement of information system, the quality of service delivery of the public sector is still declining [7]. Despite the efforts in improving the key performance indicator and producing effective adjustment to evaluate the output of the government service provider, public service is still faced with the unprecedented burden of improving their service level [8]. This response has led organisations to transform and restructure in their effort to enhance the performance of government bureaucracies and address respective management issues.

This study aims to propose a new method that will lessen the queue or waiting time at the publicsector service counter. In certain instances, clients spend several hours in line to complete a simple transaction service that usually takes just less than a minute. As a matter of fact, this condition is not considered time vindication. Furthermore, this situation could prompt the citizen to attach a bad perception to the provided service, which results into a downgrade in the public service sector's reputation. Parallel to the mission of RTD, this study was performed to address the issue of long waiting time and support the mission of RTD.

\section{Methodology}

This study's data and information sources can be categorised as either primary pr secondary data. 
Primary data is gathered using observations, time studies, semi-structured interviews, and questionnaires. Secondary data includes previously gathered and assembled historical information or data structure that was used to solve problems other than the current problem. These data was gathered from journals, books, articles, newspapers, and organisation reports.

The principle of Gemba, Gembutsu and Genjitsu was utilised as the basic concept in performing this study. Effectively utilising Gemba is an encouragement to the "go-see" principle. Gemba is used in the examination of the standard operating procedure and service process flow that occurs during the processes (Gembutsu). Several methods are used to obtain real fact and data (Genjitsu). Observations were made to monitor and gain full understanding on the current service counter practices and identify the kinds of wastes in the process. The study also espoused a more comprehensive approach that includes questionnaires and semi-structure interviews to obtain information which is more precise.

\subsection{Semi-Structure Interview}

Implementation of the semi-structure interview was done with the staff at Road Transport Department, specifically the staff working at the reception counter. Three staff members were interviewed and asked the following questions:

i. When is the busiest day and time of the services?

ii. What is the most frequent service that takes place at the counter?

\subsection{Questionnaire}

This survey aims to verify that other customers who were not there during the time study have also experienced the same issue during their time of service. For this survey, the target populations include customers who have had interactions with the RTD. The design of the questionnaire was based on similar research that was previously conducted. Another set of new questions that pertain to this study was formulated based on those sources. Furthermore, a pilot study with two experts was also performed. The primary goal of the pilot study was to ensure that a specialist panel that has experience in this area would endorse the questionnaire. Given the feedback obtained from the pilot study, an improved questionnaire set was formulated and given to the respondents. There were open ended and multiple-choice questions.

Furthermore, a usability test was performed to gather the opinion of the client about the new online system. One can define usability as a set of software to be learned, understood, utilised, and favoured by the user. The software quality characteristic's criteria were based on the ISO/IEC 25010:2011 or the ISO/IEC 9126, which is then situated as part of the usability software quality in use metrics. Table 1 presents the assessment parameters of ISO/IEC 9126 that are used in the usability study.

Table 1. Assessment Criteria of ISO/IEC 9126 under Usability Study [9]

\begin{tabular}{|c|c|}
\hline $\begin{array}{l}\text { ASSESSMENT } \\
\text { CRITERIA }\end{array}$ & DESCRIPTION \\
\hline Understandability & $\begin{array}{l}\text { Degree of the interfaces system that is user-friendly and ease to use } \\
\text { such as interface functions. }\end{array}$ \\
\hline Learnability & $\begin{array}{l}\text { The degree of which the system interfaces is capable of contributing an } \\
\text { effective documentation thus the functions could be learn quickly. }\end{array}$ \\
\hline Operability & $\begin{array}{l}\text { The ability of the interfaces to be consistent, customized and easy to } \\
\text { control. }\end{array}$ \\
\hline Attractiveness & $\begin{array}{l}\text { The capability of the system interfaces to use the software with good } \\
\text { layout and design as well as color selected. }\end{array}$ \\
\hline
\end{tabular}

The study then distributed the online questionnaire to 30 customers who had experienced the Road Transport Department's service. This represents $1 / 6$ of the amount of daily customers who were present at the RTD counter. This technique was accomplished by choosing only customers with driving licenses and who transacted at the Road Transport Department, Bukit Katil, Melaka. People with a driving license have a greater tendency to interact with this department.

\subsection{Time Study}

Time study is the main method of data collection for the duration of the service process flow. It 
followed the procedure below to conduct the stop watch time study:

- Choosing the task that has to be timed: This study records the queuing time, starting from the arrival of the customer until the end of the service.

- Standardising the working method: In this study, the time unit used is in terms of hours, minutes and seconds.

- Choosing the employee for the study: All the employees at the multipurpose counter were a part of this study.

- Breaking the task into elements.

\subsection{Observation}

The preliminary study used the observation method. It was also utilised as a supplementary technique for data collection. The study conducted the observation at random periods during the office hour. This observation aims to study the service's process flow and to roughly determine the issue that the Road Transport Department encountered. Additionally, using the observation process, the contributing factor to the long waiting time was determined. One can conclude based on the findings that there was waiting time involved during the service. Thus, to obtain more accurate and detailed data on the present situation, an in-depth continuation of the study was done using the other methods. The following information was taken note of on the observation sheet: queue number, customer time in, activity, service in, queue time, service time, time out, as well as total service time. Queue number is an indication of the customer's queue sequence. Table 2 shows the time study sheet while Table 3 shows the task element and its definition. The time taken for each element is measured using a stop watch.

Table 2. Time Study Table

\begin{tabular}{|c|c|c|c|c|c|c|c|}
\hline $\begin{array}{c}\text { Time } \\
\text { In }\end{array}$ & $\begin{array}{c}\text { Queue } \\
\text { Number }\end{array}$ & Activity & $\begin{array}{c}\text { Queue } \\
\text { Time }\end{array}$ & $\begin{array}{c}\text { Service } \\
\text { In }\end{array}$ & $\begin{array}{c}\text { Service } \\
\text { Time }\end{array}$ & $\begin{array}{c}\text { Time } \\
\text { out }\end{array}$ & $\begin{array}{c}\text { Total } \\
\text { Service } \\
\text { Time }\end{array}$ \\
\hline & & & & & & & \\
\hline
\end{tabular}

Table 3. Task Element And Definition

\begin{tabular}{|c|l|}
\hline Task Element & \multicolumn{1}{|c|}{ Definition } \\
\hline Time in & $\begin{array}{l}\text { Time when the customers obtain their queue number from the queue number } \\
\text { machine. }\end{array}$ \\
\hline Queue time & $\begin{array}{l}\text { Time spent by the customers upon collecting the queue number until they were } \\
\text { attended at the counter. (Queue Time = Service In - Time In) }\end{array}$ \\
\hline Service time & $\begin{array}{l}\text { Time taken for the customer to complete their activities at the counter which is } \\
\text { related to the worker production rate and activities time. (Service Time = Time Out } \\
\text { - Service In) }\end{array}$ \\
\hline Time out & $\begin{array}{l}\text { Time when customer completed all the required activities and left the counter. Time } \\
\text { out is assume same as service out time as after completing the process, generally } \\
\text { customer tend to directly going back. }\end{array}$ \\
\hline Total service & $\begin{array}{l}\text { Total time taken from customer taking the queue number to the time customer leave } \\
\text { the counter after service. } \\
\text { ( Total Service Time = Time In -Time Out) }\end{array}$ \\
\hline
\end{tabular}

\subsection{Online Booking System}

System analysis is considered as one of the facets involved in the examination and understanding of an existing system before a new system is developed. Analysis is performed so that the problem of the client can be determined and to make sure that the new system can meet the requirements of the client. System planning is also conducted to make sure that the system development is performed accordingly. 


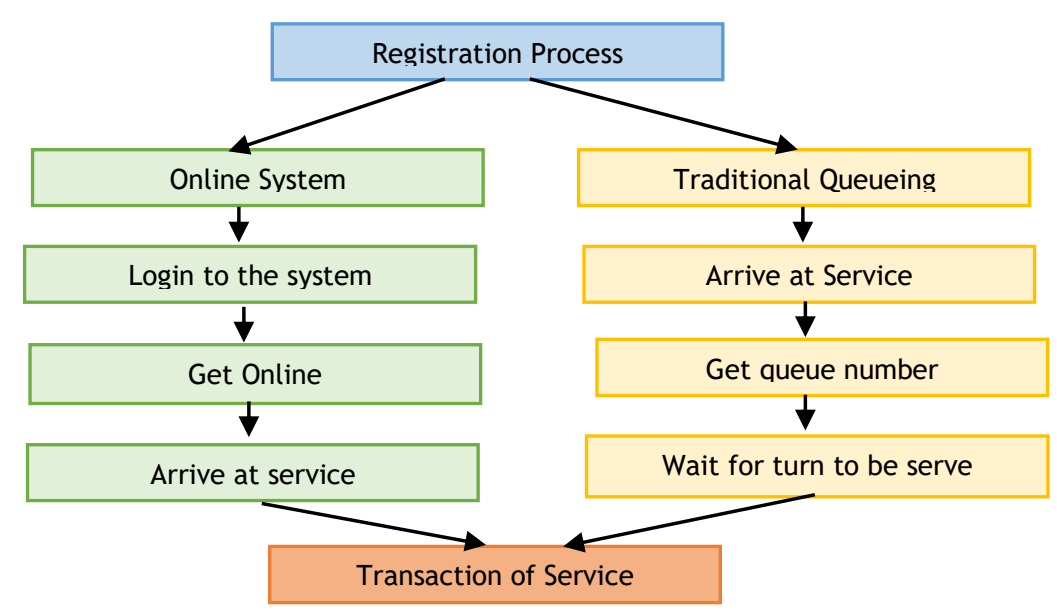

Figure 1. Comparison of Service Process Flow between New and Traditional System

Figure 1 demonstrates the process flow comparison between the new system and the traditional system. The prototyping model is considered as one of the systems development method (SDM) that allows a prototype to be built, verified, and then revised as necessary until it achieves an acceptable prototype that can be used to develop the complete product or system. Prototyping was utilised to develop the online booking system. The prototype model was developed using the following software and demonstrated in Table 4.

Table 4. List of software

\begin{tabular}{|c|c|c|}
\hline Item & Description & Version \\
\hline Adobe Dream Weaver & Platform & CS5 \\
\hline Adobe Cold Fusion & Platform & 9 \\
\hline Oracle SQL Developer & Platform & $11 \mathrm{~g}$ \\
\hline
\end{tabular}

\section{Results And Iscussion}

Table 5 shows the counter service period at RTD Bukit Katil, Melaka. During lunch break, all counters are closed except for two counters, which are dedicated for renewing driving licenses and road taxes.

For the overall services being offered, specific procedures require clients to complete some form before starting the transaction. Furthermore, other transactions, depending on the intended activity, may require cash payment. For instance, the renewal of the driving license is based on the driver's date of birth and can be renewed for up to 5 years, with RM30 as an annual payment. The form for the other transactions can be obtained via these websites;

i. $\quad h t t p: / / w w w . j p j . g o v . m y / e n / p e l e s e n a n-k e n d e r a a n$

ii. http://www.jpj.gov.my/en/pelesenan-pemandu or from the reception counter.

Table 5. Service counter operation hours [10]

\begin{tabular}{|l|l|l|l|}
\hline \multicolumn{1}{|c|}{ Day } & \multicolumn{1}{c|}{$\begin{array}{c}\text { Counter Service Hour } \\
\text { (Morning) }\end{array}$} & \multicolumn{1}{c|}{ Lunch Break } & $\begin{array}{c}\text { Counter Service } \\
\text { Hour (Evening) }\end{array}$ \\
\hline $\begin{array}{l}\text { Monday to } \\
\text { Thursday }\end{array}$ & $7.45 \mathrm{am}-1.00 \mathrm{pm}$ & $1.00 \mathrm{pm}-2.00 \mathrm{pm}$ & $2.00 \mathrm{pm}-5.00 \mathrm{pm}$ \\
\hline Friday & $7.45 \mathrm{am}-1.00 \mathrm{pm}$ & $12.15 \mathrm{pm}-2.45 \mathrm{pm}$ & $2.45 \mathrm{pm}-5.00 \mathrm{pm}$ \\
\hline
\end{tabular}

RTD counter services can be classified into 3 types, which are transaction for commercial vehicle registration, transaction of driver license, and license and transaction for the registration and license of private vehicles. The RTD website www.jpj.gov.my/en/piagam-pelanggan has the list of the transactions involved as well as the time frame for each activity. 
RTD has been increasingly burdened with numerous tasks in the hopes of improving the service level, which corresponds to significant enhancements in the country's transportation system since the 1980's [10]. In Malaysia, the vast majority of urban communities have seen important monetary and populace developments over the recent decades. Thus, in 2012, Malaysia had over 20 million registered vehicles (Ministry of Transport Malaysia, 2012) [10]. The statistical data of registered drivers and registered cars every year has proven this, as shown in Figures 2 and 3 where the trend has been consistently increasing.

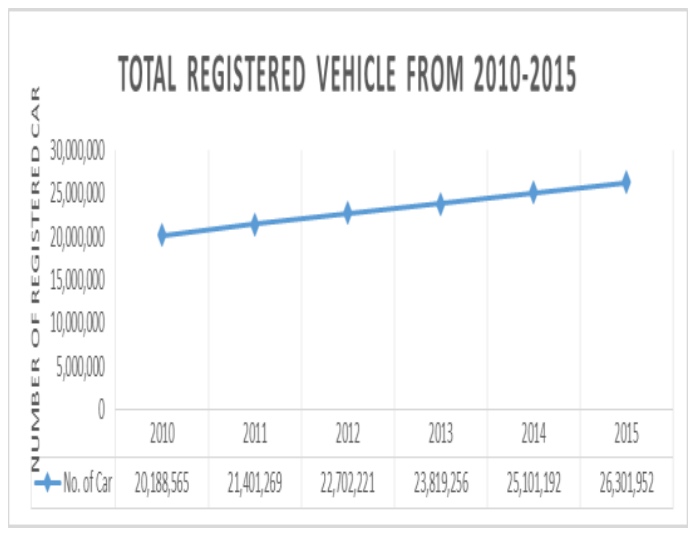

Figure 2. Number of registered cars from 2010-2015 [10]

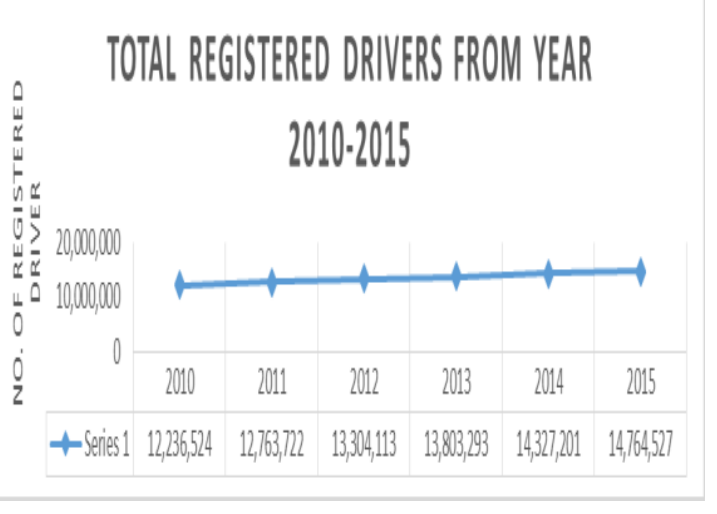

Figure 3. Number of registered drivers from 2010-2015 [10]

This created more transactions at the Road Transport Department. Based on interviews with the RTD staff, the most commonly completed transactions everyday are road tax payment, driving license renewal and new ownership registration for private vehicles. This is supported by the statistical data on RTD's total revenue, as demonstrated in Table 6.

Table 6. RTD Major Finding Revenue form Year 2012 to Year 2014 [10]

\begin{tabular}{|c|c|c|c|c|c|}
\hline $\begin{array}{l}\text { TYPE OF } \\
\text { REVENUE }\end{array}$ & $\begin{array}{l}2012 \\
\text { (RM) }\end{array}$ & $\begin{array}{l}2013 \\
\text { (RM) }\end{array}$ & $\begin{array}{c}\text { INCREMENT } \\
\text { PERCENTAGE } \\
(\%)\end{array}$ & $\begin{array}{l}2014 \\
\text { (RM) }\end{array}$ & $\begin{array}{c}\text { INCREMENT } \\
\text { PERCENTAGE } \\
(\%)\end{array}$ \\
\hline $\begin{array}{l}\text { Motorized } \\
\text { Vehicle } \\
\text { License }\end{array}$ & $\begin{array}{c}2,283,906,513 \\
.52\end{array}$ & $\begin{array}{c}2,404,056,61 \\
9.83\end{array}$ & 5.26 & $\begin{array}{c}2,528,532,063 \\
96\end{array}$ & 5.18 \\
\hline $\begin{array}{l}\text { Driving } \\
\text { License } \\
\end{array}$ & $\begin{array}{c}414,455,113.6 \\
1\end{array}$ & $\begin{array}{c}384,787,740 . \\
10 \\
\end{array}$ & -7.16 & $432,961,419.40$ & 12.52 \\
\hline $\begin{array}{c}\text { Registered } \\
\text { Number } \\
\text { Tender }\end{array}$ & $\begin{array}{c}203,686,730.2 \\
4\end{array}$ & $\begin{array}{c}198,898,457 . \\
02\end{array}$ & -2.35 & $226,061,120.12$ & 13.66 \\
\hline $\begin{array}{l}\text { Ownership } \\
\text { Transfer }\end{array}$ & $62,515,062.00$ & $\begin{array}{c}64,080,184.3 \\
0\end{array}$ & 2.5 & $70,741,899.10$ & 10.4 \\
\hline Others & $\begin{array}{c}361,578,009.9 \\
3\end{array}$ & $\begin{array}{c}400,276,460 . \\
19\end{array}$ & 10.7 & $412,443,897.18$ & 3.04 \\
\hline Total & $\begin{array}{c}3,326,141,429 \\
.30\end{array}$ & $\begin{array}{c}3,452,099,46 \\
1.44\end{array}$ & 3.79 & $\begin{array}{c}3,670,740,399 \\
76\end{array}$ & 6.33 \\
\hline
\end{tabular}

Based on Table 6, at the counter for driver license services, the rate of most client arrivals is within 2 to 43 seconds, which results into counter overcrowding since the demand is greater than the number of available staff. The capacity factor and demand can be influenced by the number of times the service was performed. Based on the receptionist staff, clients prefer to come to the RTD around $9 \mathrm{am}$ to $11 \mathrm{am}$, which is after breakfast time, in the morning session, and 2 to $3 \mathrm{pm}$, which is after the lunch break, in the afternoon session. Thus, managing the distribution of client arrival is important in avoiding long waiting times. Furthermore, the waiting time can be affected by the day when the service was conducted. The number of clients usually increases during a day after a holiday or during the festive season. Moreover, weather conditions influence clients. There are fewer clients, especially motorcyclists, during rainy season. Based on the interview, the data and the result for the time study result are presented in Table 6. It also contains information about the most frequently used service, which allows the researcher to focus on the kind of transaction system that needs to be built first.

Based on the overall result of the time study, it can be deduced that at the RTD Bukit Katil, Melaka, 
the waiting time can be over one hour and the service time is much lesser. Thus, it is not justifiable to spend a long time waiting. It does not give value to the client, especially since the actual transaction only takes a few seconds to complete. Based on observations during the time study, one of the greatest contributors to long waiting time is the surplus of demand compared to the capacity. Moreover, the waiting time is affected by the number of staff working at the counter. Waiting time may be lessened by increasing the availability of staff members who are working at the counter. In RTD, the consistency of the staff is not guaranteed everyday as some staff members may be gone for medical check-ups or outside courses. Waiting time may also be affected by the number of services performed per client. Agents or middle man that transact in place of actual drivers may disrupt the queue's smoothness. Some agents spend up to 15 minutes for one queue number and they end up conducting more than three transactions. Therefore, it is proposed that agents should have their own special counter to avoid disrupting RTD's other clients. Furthermore, waiting time may be affected by the duration of the service conducted. Some transactions may take longer compared to others. Based on the observations and the time study conducted, it has been established that customers have to wait for a specific amount time before they can be attended to at the counter. Some customers who have been waiting for a long time tend to leave their queue and therefore cause longer calling times. This situation is not a value-added activity and may contribute to more waiting time. Furthermore, it leads to more unnecessary movement when they walk to the service counter, since customers can only sit on the empty seats without being sure of what counter will attend to them. Table 7 lists other factors, issues, and solutions for longer waiting times.

Table 7. Factors, issues and suggested solution for long waiting time

\begin{tabular}{|c|c|c|}
\hline Factor & Issue & Solution \\
\hline \multirow[t]{4}{*}{ 1.Man } & $\begin{array}{l}\text { Only few counter open when } \\
\text { many clients come. }\end{array}$ & $\begin{array}{l}\text { Identify the crowded time of the day and avoid } \\
\text { the staff from taking break at that time. }\end{array}$ \\
\hline & $\begin{array}{l}\text { Clients need some time to } \\
\text { move to the counters as they } \\
\text { seat at various places. }\end{array}$ & $\begin{array}{l}\text { Indicate directly counter's number that will serve } \\
\text { the clients, so that client will seat nearby the } \\
\text { counter. }\end{array}$ \\
\hline & $\begin{array}{l}\text { The information counter is } \\
\text { far from the reception } \\
\text { counter thus client need to } \\
\text { work??? if they are asking on } \\
\text { certain requirement to fulfil } \\
\text { form. }\end{array}$ & $\begin{array}{l}\text { Placed the information counter nearby the } \\
\text { receptionist counter so that if any inquiries client } \\
\text { can directly consult with receptionist staff. }\end{array}$ \\
\hline & $\begin{array}{l}\text { Few workers at the frontline } \\
\text { counters (sick leaves, attend } \\
\text { course) }\end{array}$ & $\begin{array}{l}\text { Provide a scheduling system for customer to make } \\
\text { appointment with staff to ensure that the waiting } \\
\text { area are not overcrowded when less staff } \\
\text { available. }\end{array}$ \\
\hline \multirow[t]{3}{*}{ 2.Method } & $\begin{array}{l}\text { Variation between numbers } \\
\text { of transactions received at } \\
\text { front line counter. }\end{array}$ & $\begin{array}{l}\text { Provide special counter for customer that do } \\
\text { transaction more than } 4 \text {. }\end{array}$ \\
\hline & $\begin{array}{l}\text { Different type of service } \\
\text { receives at front counter. }\end{array}$ & $\begin{array}{l}\text { Specified counter according to specific } \\
\text { transaction at the counter to increase staff } \\
\text { working efficiency. }\end{array}$ \\
\hline & $\begin{array}{l}\text { Clients not aware on } \\
\text { document/procedure needed } \\
\text { during transaction. }\end{array}$ & $\begin{array}{l}\text { Welcome clients and notify client on procedure in } \\
\text { service that they need to do. }\end{array}$ \\
\hline \multirow[t]{2}{*}{$\begin{array}{l}\text { 3. Machin } \\
\text { e }\end{array}$} & $\begin{array}{l}\text { Card Printing machine take } \\
\text { much time to print. }\end{array}$ & Provide more printing machine \\
\hline & Machine not working. & $\begin{array}{l}\text { Provide a back-up machine } \\
\text { Revise the Standard Operating Procedure (SOP) so } \\
\text { that client will spend too much time during card } \\
\text { printing. }\end{array}$ \\
\hline
\end{tabular}


This project proposed two online systems, namely i) the RTD Queue System that is described in detail in section 4.1 and ii) the Appointment Booking System that is described in section 4.2.

\subsection{RTD Queue System}

The first proposed method is to lessen the queue at the Road Transport Department, Bukit Katil Melaka, by using an online queue booking system called the RTD Queue System. This system makes it possible for clients to book their queue number using the online system. It also allows them to arrive at the counter just in time for their service. For easy understanding, the system was built with the Malay language. Table 8 shows the system interface.

Table 8. RTD queue system interface

\begin{tabular}{|c|c|}
\hline Interface & Description \\
\hline $\begin{array}{c}\text { Login } \\
\text { Account } \\
\text { Module }\end{array}$ & $\begin{array}{l}\text { Aim: To provide interface for client to have their own account } \\
\text { - Information needed: } \\
\text { i. No. Telefon (Telephone number) } \\
\text { ii. No. Kad Pengenalan (Identification card number) } \\
\text { No. Telefon and No. Kad Pengenalan is used as identification of every client due to: } \\
\text { i. create unique id for each client } \\
\text { ii. a user-friendly method as client will carry their id card and phone with them all the time thus } \\
\text { avoid them from forgetting the password when login to the system. }\end{array}$ \\
\hline $\begin{array}{c}\text { Create } \\
\text { Account } \\
\text { Module }\end{array}$ & $\begin{array}{l}\text { - Aim: For the client to register a new account which required client to provide their details during } \\
\text { the account registration. } \\
\text { Process: } \\
\text { i. By clicking Daftar button at the main page, the system will create a new page whereby the } \\
\text { new user need enter their phone number. } \\
\text { ii. If the client failed to enter the required information, an alert message will appeared. } \\
\text { iii. Then, the process will proceed to a new page whereby client needs to complete the } \\
\text { registration form by providing their No. Kad Pengenalan, Nama Penuh and Email. } \\
\text { iv. After successfully providing all the information and clicking the Daftar button, a pop-out } \\
\text { message will appear to indicate that the user has successfully registered into the system. }\end{array}$ \\
\hline $\begin{array}{c}\text { Service } \\
\text { Booking } \\
\text { Queue } \\
\text { Module }\end{array}$ & $\begin{array}{l}\text { - Aim: Interface for client/agent to book the queue for service at RTD. } \\
\text { - The queue number can be printed at the RTD reception counter by showing their license for } \\
\text { Identification number to the receptionist staff. } \\
\text { - There are two types of customers at RTD: } \\
\text { i. Client is driver that perform their personal transaction. } \\
\text { Client need to choose which service they prefer to do either for Perlesenan Pemandu, } \\
\text { Kenderaan Persendirian and Kenderaan Perdagangan. } \\
\text { As for the other clients who intend to do more than one transaction services at a time, they } \\
\text { are allowing to do so at the same counter by only using a single queue number. } \\
\text { This is to prevent a single customer from being called upon more than once and hence, makes } \\
\text { the process flow more systematic and organised. } \\
\text { Besides, the tracking time still track the system simultaneously and no extra time spend at } \\
\text { the counter. } \\
\text { After booking, the client is also able to view the waiting duration when he/she login to the } \\
\text { system. } \\
\text { ii. Agent is a middleman that will be doing all the service transactions for the other drivers. } \\
\text { For ajen (agent) that needs to more than } 5 \text { transactions per service, they will be placed at a } \\
\text { specific counter. } \\
\text { By providing a specific counter for agent, this will help to reduce interruptions to the other } \\
\text { customers. }\end{array}$ \\
\hline $\begin{array}{l}\text { Cancel } \\
\text { Service } \\
\text { Queue } \\
\text { Module }\end{array}$ & $\begin{array}{l}\text { - For clients who have already completed booking the queue number, but intended to cancel the } \\
\text { service prior to the transaction, they are able to do so by clicking on the cancel button. }\end{array}$ \\
\hline
\end{tabular}

The design of the system interface was simplified to make sure that everyone can use it, even those who are not very knowledgeable about computer operations. Furthermore, it has a user-friendly and simple system due to the utilisation of Window, Interface Menu and Pointing devices (WIMP), which is an important feature of a computer graphic design. Capturing of the input to the online appointment booking system is done via the user interfaces that are available in the individual client 
web account and the administrator's web account. A login menu is available for each customer so that they could log in into their accounts. This login menu has a user-friendly interface for gathering the valid registration code, username, and password. Within the account, data about the customer and available staff are input and the booked appointment/number is submitted. The database stores all of these capture data. The architecture is designed in such a way that the user can access the booking system using a portable computer system or a desktop computer system as a web browser. The appointment booking system is made up of two components: the client-side that operates on the browser and the server-side. From the client-side, majority of the processing work was performed on demand at the server end and the task of the client was to presented information and data on the screen. Furthermore, clients won't need any specific PC; users can access it using any PC with a web browser, such as a desktop PC or a laptop/notebook.

\subsection{Online Appointment Booking System}

Appointment scheduling systems are utilised in managing access to service providers. The performance of appointment systems is affected by few factors, such as variability in arrival and service times, available information technology, client and provider preferences, and the scheduling staff's experience level. Thus, this criterion has to consider a proper scheduling system. An online booking system makes it possible for individuals to book their appointment online conveniently and securely. Compared to the traditional queuing method, client satisfaction could be significantly improved by the web-based appointment system with effective registration and reduced total waiting time. Below, describes the operation of the proposed online appointment booking system.

\section{Step 1: Client}

\section{Registration \& Login Menu}

For the client registration menu and login menu, client need to provide information similar to the data required for online queue booking system. Any client that does not register is allowed to access appointment booking Menu because personal data was required during the booking process to avoid information confusion when the other client claim booking the same slot.

\section{Step 2: Client}

Booking Menu

There are 3 activities that can be done through this system including booking selection, booking reschedule or cancel and overview of daily schedule.

\section{Step 3:}

\section{Booking Selection}

Upon viewing the booking selection interface, clients are required to provide information on:

i) Date Selection

The appointment booking system will be opened for public booking 2 days prior to the service day. This is to ensure that, the RTD administrative is able to allocate specific staff to manage the system.

\section{ii) RTD office selection}

The RTD office selection is categorized based on state and then RTD branch at each state. For example, if the client clicks for Melaka, then the next step he needs to do is to choose the branch of JPJ in the Melaka as shown Figure 5.
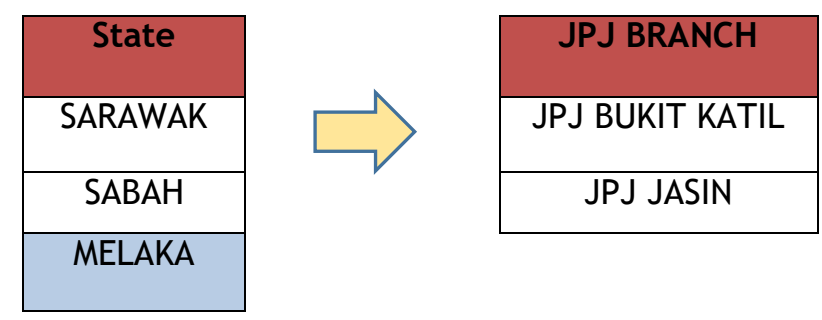

Figure 5. RTD Office Selection 


\section{iii) Service Selection}

The service selection is divided according to allocation time based on RTD's customer chartered.

\section{iv) Service Schedule}

Next, client needs to select the available schedule during the day as shown in figure 6 .

\begin{tabular}{|c|c|c|c|c|}
\hline \multicolumn{5}{|c|}{ SCHEDULE AT 9.00AM } \\
\hline $9.00 \mathrm{am}$ & $9.03 \mathrm{am}$ & $9.06 \mathrm{am}$ & $9.09 \mathrm{am}$ & $9.12 \mathrm{am}$ \\
\hline $9.15 \mathrm{am}$ & $9.18 \mathrm{am}$ & $9.21 \mathrm{am}$ & $9.24 \mathrm{am}$ & $9.27 \mathrm{am}$ \\
\hline $9.30 \mathrm{am}$ & $9.33 \mathrm{am}$ & $9.36 \mathrm{am}$ & $9.39 \mathrm{am}$ & $9.42 \mathrm{am}$ \\
\hline $9.45 \mathrm{am}$ & $9.48 \mathrm{am}$ & $9.51 \mathrm{am}$ & $9.54 \mathrm{am}$ & $9.57 \mathrm{am}$ \\
\hline
\end{tabular}

$Q=$ This sign show that the schedule has been booked by others client.

Figure 6. Service schedule

Client will be reminded about the booked service via short messaging system.

\section{Step 4:}

\section{Booking, Re-schedule/ Cancellation}

- Clients also able to reset or cancel the appointment if they are not available during the schedule.

- The new appointment can only be done up 1 hour prior to the scheduled appointment.

- If the client does not do so, he/she will be penalized from making booking for the next appointment. Figure 7 shows the reset and cancel button.

\section{Reset Cance}

Figure 7. Reset and Cancel button

- If the client clicks on Reset button, they need to fulfil again the selection pane for new appointment booking.

- But if the client clicks on the cancel button, a new notification will appear as shown in figure 8 .

\begin{tabular}{|c|c|}
\hline Are you sure to CANCEL the appointment? \\
\hline YES & NO \\
\hline
\end{tabular}

Figure 8. Notification Message

By confirming the cancel button, the cancelled slot is then opened to the public.

\section{Step 5:}

\section{Daily Schedule \& Log Out}

Aside from slot booking, client also able to just view the system to decide when to book for service.

Based on the usability test and under the understandability criteria, the respondents suggested offering a multi-language interface to create a more user-friendly system for the various races in Malaysia. Furthermore, the respondents suggested designing a system that is bookable based on their favoured time. Hence, for this study, the appointment booking system was suggested. However, this system still has its limitation. Both systems need a person to have internet connection, a personal computer, and be computer literate so that they can access the system. Thus, this system may be inaccessible when there is no internet connection in the area. Furthermore, a computer illiterate person may require assistance from the RTD staff to access to the system. 
JIE, Vol. 4, No.1, March 2019: 21-32 


\section{Conclusion}

This study proposed two kinds of online systems, which are the appointment booking system and the queue booking system with the aim of reducing the clients' waiting time at the Road Transport Department, Bukit Katil, Melaka. Furthermore, this study made it possible for management officers to uncover the issues that are often experienced at the JPJ service counter. When the issues in the system are identified and eliminated, one can develop an efficient and faster system. Furthermore, with this study, the strategy being proposed may serve as the reference and a benchmark for the continuous enhancement of the process flow for the other departments of JPJ. Furthermore, this study could serve as the reference for other non-profit organisations or public-sector services to improve their service provided as this study does not solely focus on improving the organisation's profit but also on offering high customer satisfaction level through good service.

Furthermore, it can deliver an ideal process based on the requirements of the customer. The process is made up of ideal procedures that have to be value adding, efficient (produces an excellent outcome each time), accessible (delivers the best standard and result each time), satisfactory (getting rid of waiting times), convenient, and consistent. Finally, improving the service via customer preference will help give the public sector a chance to gain confidence from the tax-paying community. With the development of this system, the goal is to be able to provide efficient service, especially towards the public service sector. A good system management is therefore important in order to create a service atmosphere that is favourable for the client.

\section{Acknowledgments}

The authors would like to thank the Fakulti Kejuruteraan Pembuatan, Universiti Teknikal Malaysia Melaka (UTeM), Ministry of Education, Malaysia and Road Transport Department Bukit Katil, Melaka.

\section{References}

1. Chan, A., 2016. Liow makes surprise visit at Wangsa Maju JPJ. Retrieved from http://www.mstar.com.my/berita/berita-semasa/2015/12/15/liow-lawatan-mengejut-jpj/

2. Teicher, J., Hughes, O., and Dow, N., 2002. E-government: a new route to public sector quality. Managing Service Quality: An International Journal, Vol.12, No.6, pp.384-393

3. Mohamad, E., Ibrahim, M.A. .Sukarma, L., Shibghatullah, A.S., Rahman, M.A.A and Salleh, M.R., 2017, Improved decision making in lean manufacturing using simulation-based approach, International Journal of Agile Systems and Management, Vol 10, Issue 1, pp 34-48.

4. Mohamad, E., Sukarma, L., Mohamad, N.A., Salleh, M.R., Rahman, M.A.A., Abdul Rahman A.A., and Sulaiman, M.A., 2018, Review on Implementation of Industry 4.0 Globally and Preparing Malaysia for Fourth Industrial Revolution, The Japan Society of Mechanical Engineers : The 28th Design Engineering System Division Lecture 2018, Yomitan village, Okinawa Prefecture, No.18-11, pp. 2203_1-2203_10, 4-6 November 2018.

5. Mohamad, E., Abd Rahman, M.S., Ito, T. and Abd Rahman, A.A., 2019, Framework of Andon Support System in Lean Cyber-Physical System Production Environment, The Japan Society of Mechanical Engineer (JSME), No.19-3 Conference 2019, Manufacturing Systems Division, 12 March 2019, Aoyama Gakuin University, Kanagawa,Tokyo, p.63-64.

6. Agus, A., Barker, S., and Kandampully, J., 2007. An exploratory study of service quality in the Malaysian public service sector. International Journal of Quality \& Reliability Management, Vol.24, No.2, pp.177-190.

7. Acland, H., 2005. Disaffected nation. Marketing, Vol. 8, pp.32-35.

8. Zakaria, Z., Yaacob, M.A., Yaacob, Z., Noordin, N., Sawal, M.Z.H.M. and Zakaria, Z., 2011. Key performance indicators (KPIs) in the public sector: a study in Malaysia. Asian Social Science, Vol.7, No.7, p.102. 2011. 
JIE, Vol. 4, No.1, March 2019: 21-32

9. Bevan, N., 2009. Extending quality in use to provide a framework for usability measurement. Human Centered Design, pp.13-22.

10. Official Portal of Road Transport Department Malaysia, 2016. Customer Charter. Retrieved from http://www.jpj.gov.my/en/piagam-pelanggan. 